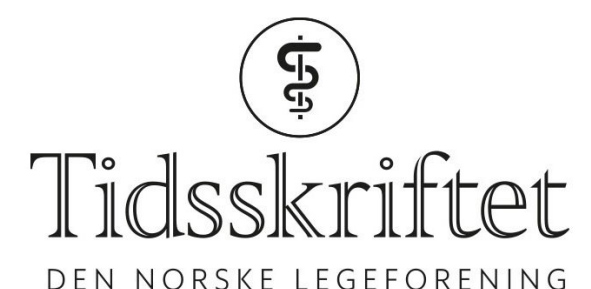

DEN NORSKE LEGEFORENING

\title{
Hjelp der den enkelte befinner seg
}

KOMMENTAR

\section{ESBEN ESTHER P. BENESTAD}

E-post: esben.esther@uia.no

Esben Esther P. Benestad er lege, familieterapeut og spesialist i klinisk sexologi NACS ved Grimstad MPAT-institutt og professor i sexologi ved Universitetet i Agder. Ingen oppgitte interessekonflikter.

\section{GUNNAR FRODE OLSEN}

Gunnar Frode Olsen er spesialist i allmennmedisin og fastlege. Ingen oppgitte interessekonflikter.

\section{JANECKE THESEN}

Janecke Thesen er spesialist i allmennmedisin og i samfunnsmedisin og forsker ved Uni Research Helse.

Ingen oppgitte interessekonflikter.

\section{HAAKON AARS}

Haakon Aars er spesialist i samfunnsmedisin, i psykiatri og i klinisk sexologi NACS ved Institutt for klinisk sexologi og terapi.

Ingen oppgitte interessekonflikter.

\section{MARI BJØRKMAN}

Mari Bjørkman er spesialist i allmennmedisin og fastlege. Ingen oppgitte interessekonflikter.

Vi setter stor pris på Åse Bjorvatn Sæviks engasjement og kommentar (1) til vår kronikk (2). Vi slutter oss til hennes avsluttende standpunkt: «Gode og kyndige møte med helsetenesta, derimot, bør styrkast i alle ledd».

Svikten i helsevesenet blir påpekt i rapporten «Rett til rett kjønn, helse til alle kjønn». Den samme rapporten anbefaler et desentralisert tilbud. Desentraliserte system er basert på pragmatikk og økonomi, støttet av forskning (3), og gir god tilgjengelighet, nærhet til helsehjelp og mulighet til bredere innsikt. Nettopp det nære, støtten fra familie og nettverk er avgjørende for denne gruppens psykiske helse.

Transpersoner er mer utsatte for traumatisering enn kontrollgruppen. Mange har blitt avvist av sine nærmeste, eller blitt sykeliggjort og henvist til «høyspesialiserte» behandlere som heller ikke har sett dem slik de ser seg selv. Verken hormonell eller kirurgisk behandling kan slette sporene etter slike traumer. Samtidig ser vi at det mest belastende for gruppen er minoritetsstress, mens støtte fra familien er det beste for god livskvalitet $(4,5)$. Det kaller på tiltak i første linje. Forslagene i «Rett til rett kjønn, helse til alle kjønn», understreker også behovet for tilgjengelig sexologisk kompetanse, noe vi støtter. 
I forståelsen av risikoen for traumatisering og minoritetsstress for de av oss som er kjønnsinkongruente, kan vi ikke vurdere nytten av hormonell og/eller kirurgisk behandling målt mot en kontrollgruppe med langt mindre sannsynlighet for liknede belastninger. Dette må måles mot hva som med sannsynlighet vil skje om den delen av behandlingen ikke tilbys.

World Professional Association for Transgender Health (WPATH) oppgraderer stadig sine Standards of Care. Der framgår at hormonell og/eller kirurgisk behandling er å betrakte som medisinsk nødvendig (6). Internasjonal konsensus sier at mange kjønnsinkongruente trenger hormonell og/eller kirurgisk behandling. Hormonbehandlingen kan gjennomføres av fastlege med kompetanse på feltet eller administreres og videreføres av fastlege som har tilgang på en sexologisk spesialisthelsetjeneste. Videre må vi se at minoritetsstress er det mest skadelige og familiestøtte det mest resiliensskapende. Det krever aktiv intervensjon, utdanning og tilstedeværelse der den enkelte befinner seg.

\section{LITTERATUR:}

1. Sævik AB. 2017. SævikAB. Er desentralisering løysinga? Tidsskr Nor Legeforen 2017. Publisert 23.11.2017.

2. Benestad EEP, Thesen J, Aars H et al. Helsevesenet svikter transpersoner. Tidsskr Nor Legeforen 2017; 137: $1686-8$.

3. Starfield B, Shi L, Macinko J. Contribution of primary care to health systems and health. Milbank Q 2005; 83: 457- 502. [PubMed][CrossRef]

4. de Vries AL, McGuire JK, Steensma TD et al. Young adult psychological outcome after puberty suppression and gender reassignment. Pediatrics 2014; 134: 696 - 704. [PubMed][CrossRef]

5. Hendricks ML, Testa RJ. A conceptual framework for clinical work with transgender and gender nonconforming clients: An adaptation of the Minority Stress Model. Prof Psychol Res Pr 2012; 43: 46o 7. [CrossRef]

6. Coleman E, Bockting W, Botzer M et al. Standards of care for the health of transsexual, transgender, and gender nonconforming people. Version 7. Int J Transgenderism 2011; 13: 165 - 232. [CrossRef]

Publisert: 5. februar 2018. Tidsskr Nor Legeforen. DOI: 10.4045/tidsskr.18.0070

(C) Tidsskrift for Den norske legeforening 2020. Lastet ned fra tidsskriftet.no 